\title{
An intensive strategies-based program: insights for literacy and socio-emotional growth of college-level students
}

\author{
Shima Ghahari ${ }^{*}$ and Fakhri Ebrahimi
}

\author{
* Correspondence: ghahary@uk.ac.ir; \\ ghaharii@gmail.com \\ Department of Foreign Languages, \\ Shahid Bahonar University of \\ Kerman, 7616914111 Kerman, Iran
}

\begin{abstract}
Strategies-based instruction (SBI), as a learner-centered and participatory approach, allows learners to be the center of attention and explicitly taught how, when, and why strategies can be used. The study reported here has investigated the effect of strategic reading instruction on enhancing reading comprehension and emotionalsocial abilities of a cohort of undergraduates at a college located in the southeastern Iran. The treatment group $(n=19)$ practiced for around 75 h (50 sessions) strategy training as well as critical and creative reading skill (higher order processing). The instruction was organized around pre-, during-, and post-tasks, and the major course books included Mosaic 2 by Wegmann and Knezevic (2007) about 60 min and Strategic Reading 2 by Richards and Eckstut-Didier (2012) for about 30 min per session. The 21 students in the control group, however, experienced a traditional reading instruction which was mainly focused on comprehension check, vocabulary development, and writing activities. Operationalized in the form presented in this study and implemented over two consecutive semesters, SBI had positive educational and psychological outcomes, although in some not all the target domains.
\end{abstract}

Keywords: Strategies-based instruction, Reading comprehension ability, Long-term experimentation, Emotional social competencies

\section{Introduction}

Learning strategies research abounds with topics related to strategies-based instruction (SBI) including identification of appropriate learning strategies, classification of strategies, effects of learner characteristics on strategy use, effect of context on strategy use, language of instruction, and methods and models of strategy instruction (Chamot, 2004). The present study set out to examine formal SBI at university-level language classrooms with a particular focus on the development of reading skill as well as emotional-social abilities of the pupils. Many researchers (Ahmadi \& Hairul, 2012; Aghaie \& Zhang, 2012; Anderson, 2005; Bedir, 2010; Bimmel et al., 2001; Dole et al., 1996; Fan, 2010; Griffiths, 2010; Harris et al., 2001; Lee 2007; Zhang, 2008; Zhicheng 1992) believe that a reader needs to be aware of and apply effective reading strategies in order to comprehend the information from the text and beyond it. According to these studies, an explicit strategy instruction may help learners in three ways: firstly, the strategies instruction can make the learning process easier; secondly, skills in using

(c) The Author(s). 2017 Open Access This article is distributed under the terms of the Creative Commons Attribution 4.0 International License (http://creativecommons.org/licenses/by/4.0/), which permits unrestricted use, distribution, and reproduction in any medium, provided you give appropriate credit to the original author(s) and the source, provide a link to the Creative Commons license, and indicate if changes were made. 
learning strategies assist learners in becoming independent, confident, and selfdirected; and finally they become more motivated as they begin to understand the relationship between their use of strategies and success in language learning (Chamot \& O’Malley 1994; Uzunçakmak, 2005).

Drawing on the previous line of research which confirms the educational and psychological potentials of SBI, the present research set out to investigate the implications of a long-term strategic reading course for the development of reading and social-emotional skills of college students.

\section{Literature review}

In what follows, a preview to the studies already done on SBI and emotional intelligence, as two major concepts in the present research, is presented.

\section{Strategies-based instruction and its covariates}

In the 1990s there was a shift from simply describing and classifying strategies to experimenting with different kinds of intervention in the classroom. Strategies-based instruction is a learner-centered teaching method which enables learners to take more responsibility for their learning: "Although initial instruction is heavily scaffold, it is gradually lessened to the point that student can assume responsibility for using the strategies independently" (Rubin et al., 2007, p. 142). This ability in regulating their own learning can make more effective and self-confident learners of them. The premise of SBI is that students should be given the opportunity to understand not only what they can learn in the language classroom, but also how they can learn the language they are studying. For so doing, language educators have suggested and applied language learning strategies (Cohen \& Macaro, 2007). According to O'Malley and Chamot (1990), language learning strategies are "the special thoughts and beliefs that individuals use to help them comprehend, learn, and retain new information" (p. 1). These strategies, which are selected consciously by the learners, are comprised of meta-cognitive, cognitive, affective and social strategies. The same taxonomy of strategies was applied in the present study. Meta-cognitive strategies deal with pre-assessment and postevaluation of language learning activities and of language use events. These strategies allow learners to control their cognition by coordinating planning, organizing, and evaluating the learning process. Cognitive strategies comprise the language learning strategies of identification, grouping, retention, and storage of language materials, as well as the language use strategies of retrieval, rehearsal, and comprehension of linguistic forms of second or foreign language. Affective strategies organize and regulate emotions, motivation, and attitude, such as reduction of anxiety and self-encouragement. Finally, social strategies are used by learners to interact with other learners and with native speakers (Cohen \& Weaver, 1998).

According to Oxford (1990), language strategies are teachable and an appropriate use of strategies "enables students to take responsibility for their own learning by enhancing learner autonomy, independence, and self-direction" (p. 10). By giving the students more responsibility for learning, language programs encouraged the learners to become more autonomous, to diagnose their own learning strengths and weaknesses, and to self-direct language learning process (Cohen \& Weaver, 1998). Moreover, strategy 
training, if designed carefully and sensitively with the learners' needs in mind, can become a key element in creative and self-directed language learning (Oxford et al., 1990; Ghahari \& Basanjideh, 2015, 2017). Therefore, the learners can benefit from coaching in learning strategies and need to become aware of the learning strategies through strategy instruction.

\section{Emotional-social abilities (or emotional intelligence)}

One of the main learner characteristics that influences learning process is intelligence. To date, many researchers believe in emotional intelligence (EI) as the most significant type of intelligence responsible for both social life and academic achievement. Goleman (1998), a distinguished psychologist in EI, believed that $80 \%$ of the reasons for any success can be accounted for by EI. According to Bar-On (2000), EI is defined as capabilities, competencies, and skills that influence one's ability to succeed in coping with daily demands and pressures. Later, Bar-On (2004, 2006) distinguished 5 emotionalsocial intelligence competencies and facilitators which were further measured by 15 subscales including 1) Intrapersonal skill comprises self-regard (accurate perception, understanding and acceptance oneself), self-awareness (awareness of and understanding one's emotions), assertiveness (effective expression of one's emotions and oneself), autonomy (self-reliance and freedom from emotional dependency on others), and selfactualization (striving to achieve personal goals and actualize one's potential), 2) Interpersonal skill comprises empathy (awareness of and understanding how others feel), social responsibility (identification with one's social group and cooperation with others), and interpersonal relationship (mutual satisfying relationship with others, 3) Stress management consists stress tolerance (effective management of stresses and pressures) and impulse control (effective controlled emotions), 4) Adaptability is made up of reality testing (objective validation one's feelings and thinking with external reality), flexibility (adaptation and adjustment one's feeling and thinking to new situations), and problem-solving (effectively problem-solving of a personal and interpersonal nature), and 5) General mood comprises optimism (being positive and looking at the brighter side of life) and happiness (content feeling with oneself, others, and life in general).

Since the conception of EI, there has been a growing interest among researchers to comparatively investigate its relationship with academic achievement, foreign language learning, and strategy use (Berenji, 2010; Pishghadam, 2009; Zafari \& Biria, 2014; Zarafshan, 2012; Zarezadeh, 2013). These studies have concluded that total EI and its subscales can predict learners' strategies use and the influence of some sub-scales of EI on the choice of learning strategies. According to Zarafshan (2012), EI sub-scales which affect reading skill include stress management, adaptability, and general mood. Shang (2010) documented the relationship between reading strategy use (i.e. cognitive, metacognitive, and compensation strategies) and perceived self-efficacy on learners' foreignlanguage reading achievement.

\section{Research questions and rationale}

SBI, as a learned-centered approach, has two major characteristics: 1) learners are the center of attention and are taught how, when, and why strategies can be used, and 2) strategies may be explicitly or implicitly embedded into language tasks (Chamot \& 
Rubin, 1994). Today, it has been well recognized that the efficacy of SBI is affected by different learner-internal and -external variables and that it can be configured in a variety of ways. This study, in fact, was motivated by the previous research which showed that SBI can be implemented both explicitly and implicitly (Aghaie \& Zhang, 2012; Chamot \& Rubin, 1994; Cohen \& Weaver, 1998; Gu, 2007) and has differential outcomes depending on the length of the instruction (Carrell 1998; Lee 2007), on the stages of learning, namely elementary, intermediate, and advanced levels (Tayler, Stevens, \& Asher, 2006; Walters, 2006), educational settings such as schools, universities, and non-profit institutes (Fan, 2010), and different language skills (Cohen, 2011; Hardan, 2013). In this respect, this research was considerably narrowed down to study the effect of a long-term explicit SBI at a university reading course with the participants who were above the average (intermediate) proficiency level. Research has also established that SBI has been correlated with (affected by and affecting) a number of positive personality traits such as autonomy, self-regulation, self-efficacy, and sense of responsibility (Butler, 2002; Chamot, 2004; Chan, 2003; Cotterall, 2000; Nguyen \& Gu, 2013; Oxford 1999; Schunk \& Zimmerman, 2007; Wenden 1995; White, 1995).

To sum up, the general objectives of this project were four-fold: a) to deal with language learners' reading problems in the university context and improve the quality of reading courses, b) to pursue the psychological potentials of language learning classrooms and practices by investigating, as a case in point, the effect of SBI on EI ability, c) to investigate the actual efficacy of strategies-based language programs by operationalizing a longitudinal and intensive SBI, and finally d) to encourage language teachers, policy makers, and syllabus designers to consider multiple options in reading courses and textbooks and thereby take full advantage of the educational and sociopsychological dynamics of this macroskill training. The study was therefore organized around the following questions:

- Does SBI enhance reading comprehension of language learners?

- Does SBI affect language learners' EI competency?

- Is there any significant difference between the effectiveness of SBI on different subscales of EI?

\section{Methods}

\section{Sample and setting}

Participants of this study were freshmen B.A. students of English language and literature at a state university in the southeastern of Iran. They were two intact classes (one control and one treatment) whose age ranged from 18 through to 38 years. The initial number of the students was 50; after data collection and scoring, some sample reduction occurred as a result of which a total of 40 participants (19 in the treatment group and 21 in the control group) remained for further analysis (16 males and 24 females). Both groups received the treatments in their reading comprehension courses 1 and 2 but with different instructors, methodologies, and reading course books. On the basis of a proficiency test results, the English level of the sample was found to be homogeneous ( $M=60$ out of $90, S D=2.3, p>.05)$ and about intermediate. 


\section{Instrumentation}

The current study involved two sets of tests: 1) an emotional quotient inventory for measuring the level of EI and 2) a reading comprehension test battery for measuring the students' mastery of reading comprehension and reading strategies. Further elaboration of each instrument is provided below.

\section{Emotional quotient inventory}

Bar-On's (1997) emotional quotient inventory (EQ-I) is a 133-item self-report measure of EI containing five expansive areas of skills and its sub-skills including intrapersonal skills, interpersonal competence, stress management, adaptability, and general mood. The items are presented in the form of declarative statements phrased in the firstperson singular. The subjects are asked to rate to the statement on a 5-point Likert scale ranging from very seldom or not true of me to very often or true of me. Upon using KR-21, the reliability of this test was found to be .70 in the present study.

\section{Reading comprehension test battery}

The reading exam, the scores of which were considered as reading comprehension achievement in this study, was adopted from Ghahari and Basanjideh (2015). In order to test the students' mastery of reading comprehension and reading strategies, the reading comprehension test battery (henceforth RCTB) had been organized around three subsections. The first part contained a passage with 12 multiple-choice questions asking for finding main idea, recalling details, understanding sequence, comparing and contrasting, finding word meaning in context, distinguishing between fact and opinion, interpreting figurative language, recognizing cause and effect, making predictions, drawing conclusions and making inferences, identifying author's purpose, and choosing the best summary. The second part of the exam provided a shorter passage followed by more general multiple choice items with two questions demanding the students to make inferences about specific parts of the passage and one item eliciting its genre. The last section of the exam was composed of six sentences and short paragraphs. Each of them was followed by one up to three supply questions requiring the students to make inferences ( 3 items), to guess the meaning of words/phrases from context ( 2 items), to identify the word/pronoun references ( 2 items), and to paraphrase the underlined expressions or phrases ( 1 item). Overall, then, RCTB was made up of 23 items with 15 multiple-choice and 8 short-answer questions. The reliability of the test was estimated to be .67 .

\section{Application of teaching practice}

The data for this study was collected from September 2013 through to June 2014 by administering pre- and post-intervention tests. The participants sat for this study for two consecutive semesters (around 50 one-and-half-an-hour sessions). In the first session, both groups received the EI test as a pre-test and began to receive their preplanned reading course instruction the same session. Prior to the EI test administration, the students gave informed consent and were ensured that their anonymity would be strictly protected. Moreover, they were notified that they would be awarded course credit if they filled it out fully and accurately. Guidelines were offered for the items students found ambiguous or confusing and a total of $50 \mathrm{~min}$ was allotted to the completion of the whole test. 
In the treatment group, which was taught by the first author, two books were practiced: 1) Mosaic 2 by Wegmann and Knezevic (2007) about 60 min per session and 2) Strategic Reading 2 by Richards and Eckstut-Didier (2012) for about 30 min. Mosaic 2 (Wegmann \& Knezevic, 2007) consists of a number of a) reading strategies, b) critical thinking activities, c) vocabulary building tasks, and d) testing and evaluation practices. The strategies which are, more or less, common across all the chapters include previewing a reading for its organization, skimming for main idea, scanning for specific information, making inferences, identifying the theme, reading for fluency and speed, identifying the key people and elements in a story, comparing genres of writing, and predicting story events. Among the critical thinking skills are comparing ideas about a reading, summarizing group opinions, drawing conclusion from the chart, clarifying ideas and speculating, paraphrasing, analyzing the facts, evaluating opinions, supporting and challenging a hypothesis, analyzing the author's point of view, separating fact from opinion, and analyzing cause and effect. The other book was Strategic Reading (Richards \& Eckstut-Didier 2012) which is organized around tasks such as reading preview, skimming, and scanning, post-reading tasks such as comprehension check, vocabulary study, reading strategy, and relating reading to personal experience, and finally timed reading.

In the control group, which was trained by a different instructor, the students practiced reading comprehension activities, vocabulary development, and writing skill with a primary emphasis on narrative texts. Each session, two books were practiced: 1) Patterns Plus by Conlin (2011) for about $60 \mathrm{~min}$ and 2) Modern Short Stories by Taylor (1968) for around 30 min. Patterns Plus (Conlin, 2011) includes the description of the basics of the writing process, the ways texts are developed, and the construction of paragraphs and essays. In that, various techniques used in developing the main idea of a paragraph and thesis of an essay (i.e. narration, description, and the expository modes, as well as classification and division, comparison and contrast, process, cause and effect, argumentation, and persuasion) are explained. The supplementary book, Modern Short Stories (Taylor 1968), contains short stories on a wide range of themes and styles of writing. The questions at the end of each story are followed by a selection of idiomatic phrases and constructions in common usage, as well as prompts for further discussion and writing practice on the significant ideas in the stories.

Both groups were instructed over 50 sessions and around 90 min per session. Afterwards, EQ-I (50 min) was re-administered as post-test to the two classes followed by the RCTB (40 min).

\section{Results}

Kolmogorov-Smirnov normality test was utilized to determine whether or not the data is normal. Since the distribution of the data for both groups met the normality criterion $(p>.05)$, parametric statistics was used for data analysis. In order to test the first research question and see the enhancement of reading comprehension after SBI, RCTB was administered to both groups. Table 1 represents the two groups' performance details. The mean score of the control and the treatment groups were 11.94 $(S D=3.35)$ and $15.95(S D=4.66)$, respectively. In other words, the students in the treatment group received a higher mean score than the contrast group, which shows an improvement in this group' reading ability. 
Table 1 Groups' Composition in terms of Reading Posttests Performance

\begin{tabular}{llllll}
\hline & \multicolumn{2}{l}{ Posttests } & & & Total \\
\cline { 2 - 5 } & Min & Max & Mean & SD & \\
\hline Control & 6 & 19 & 11.94 & 3.35 & 18 \\
Treatment & 8 & 23 & 15.95 & 4.66 & 19 \\
\hline
\end{tabular}

To find out whether any progress was made as a result of the treatments, an independent samples $t$-test was run on the posttest scores (Table 2). The results of the Levene's test approved the equality of the two groups' variances $(F=2.743, p>.05)$.

As it is indicated in Table 2, the treatment group performed significantly better than the control group $\left(t_{(35)}=-2.985, p<.01\right)$. Therefore, the treatment group made significantly more reading gains out of the instruction and the positive effect of SBI on the enhancement of reading comprehension is confirmed. So the null hypothesis which stated that SBI does not enhance reading comprehension of language learners was rejected. The same finding is schematically presented in Fig. 1 below where the treatment group's (represented by 2 in the horizontal line) scores are markedly above those of the control group.

The second research question asked whether SBI affects language learners' EI competency. Table 3 below summarizes the distribution and performance of the two groups on EI pre- and post-tests. According to the descriptives, the control group has performed better in both the pretest $(M=322.38)$ and posttest $(M=321.67)$ than the treatment group which received mean scores of 282.89 and 301.84 in the same tests, respectively. Although the mean performance of the control group was slightly higher than the treatment group in the post-instruction condition, the latter $(S D=54.01)$ turned out to be radically more homogeneous than the control group $(S D=70.89)$.

In order to test this hypothesis and for comparing the groups' EI ability before and after the treatment, two paired-samples tests (i.e. within-group comparisons) were run (Table 4). As can be seen, the drop in the mean performance of the control group was not statistically significant $\left(t_{(20)}=.042, p>.05\right)$ suggesting that no significant EI gain or loss happened for this group over the course of the normal instruction they received. The same results were achieved for the treatment group which did not make any significant improvement along this period of time $\left(t_{(18)}=-1.269, p>05\right)$. Therefore, SBI did not affect the learners' EI competency and the null hypothesis stating that SBI does not affect EI ability was confirmed.

The last research question was addressed by testing the following null hypothesis: There is not any significant difference between the effectiveness of SBI on different subscales of EI. A one-way ANOVA was conducted to inferentially analyze and compare the scores of the treatment and control groups on EI subscales. The results are presented in Table 5 below. An inspection of this table reveals a significant effect on intrapersonal skills $(F=3.195, p<.05)$ and no significant effect on interpersonal relationship $(F=.180, p>.05)$, adaptability $(F=1.989, p>.05)$, stress management $(F=.917$, $p>.05)$, general mood $(F=.182, p>.05)$.

Table 2 Comparison of Reading Posttests across Groups

\begin{tabular}{lllll}
\hline & SED & Mean difference & $\mathrm{t}$ & $\mathrm{df}$ \\
\hline Treatment ${ }^{*}$ Control & 1.341 & -4.003 & $-2.985^{* *}$ & 35 \\
\hline SED Standard error difference, ${ }^{* *} p<.01$ & &
\end{tabular}




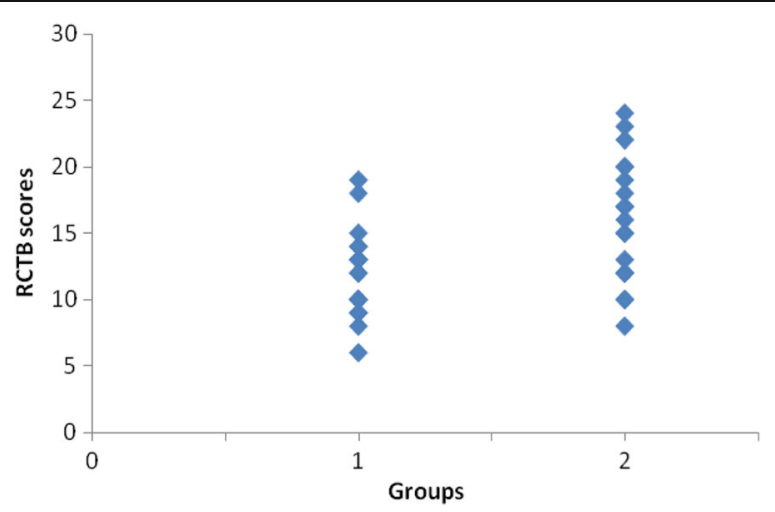

Fig. 1 RCTB performance across groups

Therefore, all other things being equal, the treatment group obtained better results in intrapersonal skills and SBI did affect the development of this component. It did not, however, contribute to other areas including interpersonal relationship, adaptability, stress management, and general mood $(p>.05)$. Figure 2 illustrates the development of intrapersonal skill over the course of instruction across the two groups. Unlike the treatment group, marked by 3 (pretest) and 4 (posttest), which noticeably improved in intrapersonal ability, no remarkable gain in this time period was made by the control group, represented by 1 and 2 respectively for pre- and post-intervention conditions.

Table 6 below provides a summary of the results. Accordingly, the treatment group has outperformed the other group in reading comprehension and intrapersonal competency. In the overall EI ability and other EI subscales, however, no significant gain was observed in any of the two groups over the course of study.

\section{Discussion and conclusion}

Three research questions were investigated through this study. The first question was whether SBI would have any effect on enhancing reading comprehension of language learners. The answer was positive. This finding is in tune with the results of previous studies like Carrell (1998), Dole et al. (1996), and Macaro (2006), which found strategy training making the learners more aware of the active nature of learning and more capable of employing problem-solving and trouble-shooting routines to enhance understanding; it therefore shows that reading comprehension could be improved through regular and explicit instruction on language learning strategies. Among other studies existing in the literature which showed the positive effect of teaching reading strategies on enhancing students' reading comprehension ability are Aghaie and Zhang (2012), Bimmel et al. (2001), Eker (2014), Farrell (2001), Lau and Chan (2003), Plonsky (2011),

Table 3 Groups' Composition in terms of El Performance across Testing Sessions

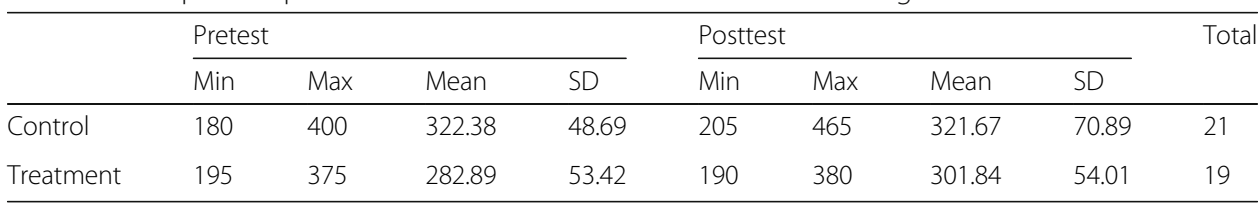


Table 4 Cross-Comparison of Groups' El Ability across Test Conditions

\begin{tabular}{lllll}
\hline & SEM & $\mathrm{t}$ & $\mathrm{Sig}$ & $\mathrm{df}$ \\
\hline Control & 16.819 & .042 & .967 & 20 \\
Treatment & 14.934 & -1.269 & .221 & 18 \\
\hline
\end{tabular}

SEM Standard error mean

Salataci and Akyel (2002), Tayler et al. (2006), Zhang (2008), and Zhussupova and Kazbekova (2016).

The second research question concerned in this study was whether SBI would have an effect on language learners' EI competency. The results indicated no significant differences in the overall EI ability of the treatment and control groups in the posttest condition. There is further evidence in the literature (e.g., Berenji, 2010; Pishghadam, 2009) in support of an insignificant correlation between total EI and academic performance, but these studies found some sub-scales of EI as good predictors of academic achievement. According to Berenji, some helpful techniques which can be used to increase EI ability in language classroom include discussion, asking students' opinions on different subjects, and presenting reading texts which motivate them to be more familiar with themselves especially their emotional aspects. One possible explanation for finding no causal relation between SBI and EI could be the length and nature of the instruction. In educational psychology, in order to improve psychological traits like EI, extensive explicit instructional packages are presented to the patients. As SBI is considered as an indirect treatment for enhancing EI and given that EI is partly an inborn and stable feature, a longer and more explicit instruction seems to be more effective than the strategy training practiced in this study.

Finally, we sought whether SBI affects language learners' EI five sub-scales of intrapersonal skills, interpersonal competence, stress management, adaptability, and general mood. While there were not any meaningful differences in the pre- and post-tests of the control group, SBI enhanced the intrapersonal skill of the treatment group.

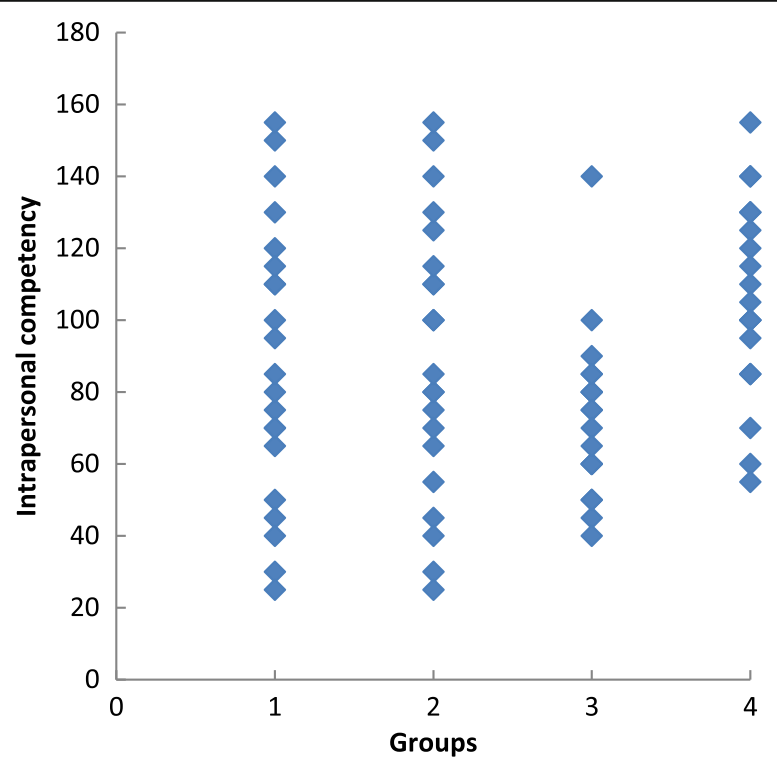

Fig. 2 Intrapersonal competency across groups 
Table 5 Summary of ANOVA Results for El Subscales

\begin{tabular}{|c|c|c|c|c|c|c|}
\hline & & Sum of Squares & $\mathrm{df}$ & Mean Square & $\mathrm{F}$ & Sig. \\
\hline \multirow[t]{3}{*}{ IntraS } & Between Groups & 10466.104 & 3 & 3488.701 & 3.195 & .028 \\
\hline & Within Groups & 82983.584 & 76 & 1091.889 & & \\
\hline & Total & 93449.688 & 79 & & & \\
\hline \multirow[t]{3}{*}{ InterS } & Between Groups & 441.298 & 3 & 147.099 & .180 & .910 \\
\hline & Within Groups & 62055.890 & 76 & 816.525 & & \\
\hline & Total & 62497.188 & 79 & & & \\
\hline \multirow[t]{3}{*}{ Adaptability } & Between Groups & 3886.342 & 3 & 1295.447 & 1.989 & .123 \\
\hline & Within Groups & 49488.346 & 76 & 651.162 & & \\
\hline & Total & 53374.687 & 79 & & & \\
\hline \multirow[t]{3}{*}{ StressM } & Between Groups & 1180.251 & 3 & 393.417 & .917 & .437 \\
\hline & Within Groups & 32599.749 & 76 & 428.944 & & \\
\hline & Total & 33780.000 & 79 & & & \\
\hline \multirow[t]{3}{*}{ Mood } & Between Groups & 204.060 & 3 & 68.020 & .182 & .908 \\
\hline & Within Groups & 28425.940 & 76 & 374.026 & & \\
\hline & Total & 28630.000 & 79 & & & \\
\hline
\end{tabular}

IntraS intrapersonal skill, InterS interpersonal skill, StressM stress management

Considering the constituents of intrapersonal skill which is conceptualized as comprising self-regard (accurate perception, understanding and acceptance oneself), selfawareness (awareness of and understanding one's emotions), assertiveness (effective expression of one's emotions and oneself), independence (self-reliance and freedom from emotional dependency on others), and self-actualization (striving to achieve personal goals and actualize one's potential), SBI has, therefore in this study, enhanced language learners' self-esteem, self-efficacy, self-evaluation, self-regulation, and autonomy. Similar findings have been observed in previous research (e.g., Berenji, 2010; Nguyen \& Gu, 2013; Oxford, 1990, 1999; Pishghadam, 2009; White, 1995).

Overall, the findings of this study support the studies into the psychological advantages of strategy use along with its pedagogical benefits. Among these psychological outcomes are autonomy (e.g., Chamot et al., 2010; Nguyen \& Gu, 2013) and selfefficacy (e.g., Shang, 2010; Yui \& Hassan, 2015), both of which belonging to intrapersonal competency. One can conclude, then, that strategy awareness, appropriate use of reading strategies, and transferring them to new situations can intensify learners' motivation by increasing their confidence and expectation of success; when the students are confident and motivated enough, they anticipate the worth of their learning, turn to

Table 6 Summary of the results

\begin{tabular}{ll}
\hline Target domain & Groups comparison \\
\hline Reading comprehension & Treatment group $>$ Control group \\
El & n.s. \\
Intrapersonal ability & Treatment group $>$ Control group \\
Interpersonal ability & n.s. \\
Adaptability & n.s. \\
Stress management & n.s. \\
General mood & n.s. \\
\hline n.s. nonsignificant &
\end{tabular}


be more self-reliant on their ability to use reading strategies, and become better able to learn independently. This can further lead to an enhancement in such life qualities as autonomy and self-efficacy. Similarly, the more frequently they use strategies in reading comprehension classroom, the more confidence and personal control they will have over their reading skills, and the higher self-perception of learning outcomes they will obtain.

Moreover, this study, like similar ones (e.g., Conte, 2005; McNamara, 2005; Petrides \& Furnham, 2000; Sivanathan \& Fekken, 2000), highlights the trainability of EI and supports practically useful techniques for enhancing EI competency. EI is a dynamic construct and always continues to develop as learners learn from experiences in longitudinal training programs.

Given its educational and psychological potentials, SBI can be investigated in the future on several grounds. The most essential variable in strategy training might be the time factor; much time would be needed to achieve more significant results on the effect of SBI on language learning and EI ability. Further research is also recommended to include a larger sample size and therefore to increase the generalizability of the findings. The focus of attention in this study was on Iranian high intermediate students and reading macroskill. It is suggested that interested researchers investigate the degree of success of students in other language contexts, language proficiency levels, and language skills.

\section{Authors' contributions}

Shima Ghahari was the instructor of the experimental group, set up the design of the study, was the tests developer, performed the statistical analysis, and reviewed and revised the manuscript. Fakhri Ebrahimi was the tests administrator, drafted the manuscript, and reviewed and revised it. Both authors read and approved the final manuscript.

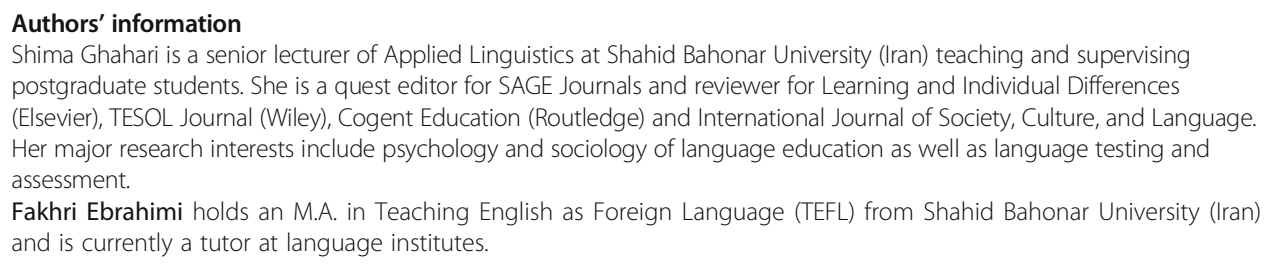
postgraduate students. She is a quest editor for SAGE Journals and reviewer for Learning and Individual Differences (Elsevier), TESOL Journal (Wiley), Cogent Education (Routledge) and International Journal of Society, Culture, and Language. Her major research interests include psychology and sociology of language education as well as language testing and assessment.

Fakhri Ebrahimi holds an M.A. in Teaching English as Foreign Language (TEFL) from Shahid Bahonar University (Iran) and is currently a tutor at language institutes.

Competing interests

The authors declare no conflicts of interest with respect to the content, authorship, and/or publication of this article.

\section{Publisher's Note}

Springer Nature remains neutral with regard to jurisdictional claims in published maps and institutional affiliations.

Received: 15 February 2017 Accepted: 13 July 2017

Published online: 28 July 2017

\section{References}

Aghaie, R., \& Zhang, L. (2012). Effects of explicit instruction in cognitive and metacognitive reading strategies on Iranian EFL students' reading performance and strategy transfer. Instructional Science, 40, 1063-1081.

Ahmadi, M., \& Hairul, N. (2012). Reciprocal teaching as an important factor of improving reading comprehension. Journal of Studies in Education, 2(4), 153-173.

Anderson, N. (2005). L2 learning strategies. In E. Hinkel (Ed.), Handbook of research in second language teaching and learning (pp. 757-772). Mahwah, NJ: Lawrence Erlbaum.

Bar-On, R. (1997). The emotional quotient inventory (EQ-1): A test of emotional intelligence. Toronto, Canada: Multi-Health System.

Bar-On, R. (2000). Emotional and social intelligence: insights from emotional quotient inventory. In J. D. A. Parker (Ed.), The handbook of emotional intelligence (pp. 363-390). San Francisco: Jossey-Bass.

Bar-On, R. (2004). The Bar-on emotional quotient inventory (EQ-I): rationale, description, and summary of psychometric properties. In G. Geher (Ed.), Measuring emotional intelligence: common ground and controversy (pp. 111-142). Hauppauge, NY: Nova. 
Bar-On, R. (2006). The Bar-On model of emotional-social intelligence (ESI). Psicothema, 18, 13-25.

Bedir, H. (2010). Teachers' beliefs on strategies based instruction in EFL classes of young learners. Procedia - Social and Behavioral Sciences, 2, 5208-5211.

Berenji, S. (2010). The relationship between emotional intelligence and students' academic achievements in general EFL classes. The Journal of Applied Linguistics, 3(2), 52-68.

Bimmel, P., Van den Bergh, H., \& Oostdam, R. J. (2001). Effects of strategy training on reading comprehension in firs and second language. European Journal of Psychology of Education, 16, 509-529.

Butler, D. L. (2002). Individualizing instruction in self-regulation learning. Theory Into Practice, 41(2), 81-92. doi:10.1207/ s15430421tip4102_4

Carrell, P. (1998). Can reading strategies be successfully taught? Australian Review of Applied Linguistics, 21, 1-20.

Chamot, A. (2004). Issues in language learning strategies research and teaching. Electronic Journal of Foreign Language Teaching, 1(1), 14-26.

Chamot, A., \& O'Malley, J. (1994). The CALLA handbook: How to implement the cognitive academic language learning approach. Reading, MA: Addison-Wesley.

Chamot, A. U., \& Rubin, J. (1994). Comments on Janie Rees-miller's "a critical appraisal of learner training: theoretical bases and teaching implications". TESOL Quarterly, 28(4), 771-776.

Chamot, A., Keatley, C., Meloni, C., Gonglewski, M., \& Bartoshesky, A. (2010). Developing autonomy in lanquage learning: learning strategies instruction in high education. Washington, DC: National Capital Language Resource Center.

Chan, V. (2003). Autonomous language learning: the teachers' perspectives. Teaching in Higher Education, 8(1), 33-54. doi:10.1080/1356251032000052311.

Cohen, A. (2011). Focus on the language learner: styles, strategies and motivation. In N. Schmitt (Ed.), An introduction to applied linguistics (pp. 161-178). London: Hodder Education.

Cohen, A., \& Macaro, E. (2007). Language learner strategies: thirty years of research and practice. Oxford, UK: Oxford University Press.

Cohen, A., \& Weaver, S. (1998). Strategies-based instruction for second language learners. In W. A. Reyandya \& G. M. Jacobs (Eds.), Learners and language learning anthology series (pp. 1-25). Singapore: SEAMED. Regional Language Center.

Conlin, M. (2011). Patterns plus: a short prose reader with argumentation. Boston, Mass.: Houghton Mifflin.

Conte, J. (2005). A review and critique of emotional intelligence measures. Journal of Organizational Behavior, 26, 433-440.

Cotterall, S. (2000). Promoting learner autonomy through the curriculum: principles for designing language courses. ELT Journal, 54(2), 109-117.

Dole, J., Brown, K., \& Trathen, W. (1996). The effects of reading instruction on the comprehension performance of at-risk students. Reading Research Quarterly, 31(1), 62-88.

Eker, C. (2014). The effect of teaching practice conducted by using metacognition strategies on students' reading comprehension skills. International Online Journal of Educational Sciences, 6(2), 269-280.

Fan, Y. (2010). The effect of comprehension strategy instruction on EFL learners' reading comprehension. Asian Social Science, 6(8), 19-29.

Farrell, T. (2001). Teaching reading strategies: It takes time. Reading in a Foreign Language, 13, 631-646.

Ghahari, S., \& Basanjideh, M. (2015). Dynamics of strategies-based language instruction: a study of reading comprehension and problem solving abilities via structural equation modeling. RELC Journal, 46(3), 237-253.

Ghahari, S., \& Basanjideh, M. (2017). Psycho-linguistic model of reading strategies awareness in EFL contexts. Reading Psychology, 38(2), 125-153.

Goleman, D. (1998). Working with emotional intelligence. New York: Bantam Books.

Griffiths, C. (2010). Strategies of successful language learners. JELS, 1(3), 1-18.

Gu, Y. (2007). Strategies-based instruction. In T. Yashima \& T. Nabei (Eds.), Proceedings of the international symposium on English education in Japan: exploring new frontiers (pp. 21-38). Osaka: Yubunsha.

Hardan, A. (2013). Language learning strategies: a general overview. Procedia - Social and Behavioral Sciences, 106, 1712-1726.

Harris, V., Gaspar, A., Jones, B., Ingvadottir, H., Palos, l., Neuburg, R., \& Schindler, L. (2001). Helping learners learn: exploring strategy instruction in language classroom across Europe. Graz, Austria: European Centre for Modern Language.

Lau, K., \& Chan, D. (2003). Reading strategy use and motivation among Chinese good and poor readers in Hong Kong. Journal of Research in Reading, 26(2), 177-190.

Lee, K. (2007). Strategy Awareness - Raising for Success: Reading Strategy Instruction in the EFL Context. (Published dissertation). College Park: Department of Curriculum and Instruction, University of Maryland.

Macaro, E. (2006). Strategies for language learning and for language use: revising the theoretical framework. Modern Language Journal, 90, 320-337.

McNamara, J. (2005). The trainability of emotional intelligence. Retrieved from http://www.academia.edu/2020034/The Trainability of Emotional_Intelligence.

Nguyen, L., \& Gu, Y. (2013). Strategy-based instruction: a learner-focused approach to developing learner autonomy. Language Teaching Research, 17(1), 9-30.

O'Malley, J., \& Chamot, A. (1990). Language strategies in second language acquisition. Cambridge: Cambridge University Press.

Oxford, R. (1990). Language learning strategies: what every teacher should know. New York: Newbery House.

Oxford, R. (1999). Relationship between second language learning strategies and language proficiency in the context of learner autonomy and self-regulation. Revista Canaria de Estudios Ingleses, 30, 109-126.

Oxford, R., Crookall, D., Cohen, A., Lavine, R., Nyikos, M., \& Sutter, W. (1990). Strategy training for language learner: Six situational case studies and a training model. Foreign Language Annuals, 22(3), 197-216.

Petrides, K., \& Furnham, A. (2000). On the dimensional structure of emotional intelligence. Personality and Individual Differences, 29, 313-320.

Pishghadam, R. (2009). A quantitative analysis of the relationship between emotional intelligence and foreign language learning. Electronic Journal of Foreign Language Teaching, 6(1), 31-41.

Plonsky, L. (2011). The effectiveness of second language strategy instruction: a meta-analysis. Language Learning, 61, 993-1038. 
Richards, J., \& Eckstut-Didier, S. (2012). Strategic reading. Cambridge: Cambridge University Press.

Rubin, J., Chamot, A., Harris, V., \& Anderson, J. (2007). Intervening in the use of strategies. In A. D. Cohen \& E. Macaro (Eds.), Language learner strategies: 30 years of research and practice (pp. 141-160). Oxford: Oxford University Press.

Salataci, R., \& Akyel, A. (2002). Possible effects of strategy instruction on L1 and L2 reading. Reading in a Foreign Language, 14, 1-17.

Schunk, D. H., \& Zimmerman, B. J. (2007). Influencing children's self-efficacy and self-regulation of reading and writing through modeling. Reading and Writing Quarterly, 23, 7-25.

Shang, H. (2010). Reading strategy use, self-efficacy and EFL reading comprehension. The Asian EFL Journal Quarterly, 12(2), 18-42.

Sivanathan, N., \& Fekken, G. (2000). Emotional intelligence, moral reasoning, and transformational leadership. Leadership \& Organization Development Journal, 23(4), 198-240.

Tayler, A., Stevens, J., \& Asher, J. (2006). The effects of explicit reading strategy training on L2 reading comprehension. In J. Norris \& L. Ortega (Eds.), Synthesizing research on language learning and teaching (pp. 213-244). Philadelphia: Benjamins.

Taylor, P. (1968). Modern short stories. London: Oxford University Press.

Uzunçakmak, P. (2005). Successful and unsuccessful readers' use of reading strategies (master's thesis). department of teaching English as a foreign language. Ankara: Bilkent University.

Walters, J. M. (2006). Methods of teaching inferring meaning from context. RELC, 37, 176-190. doi:10.1177/ 0033688206067427.

Wegmann, B., \& Knezevic, M. (2007). Mosaic: Reading. England: McGraw-Hill Companies.

Wenden, A. (1995). Learner training in context: a knowledge-based approach. System, 23(2), 183-194.

White, C. (1995). Autonomy and strategy use in distance foreign language learning: research findings. System, 23(2), $207-221$.

Yui, L., \& Hassan, N. (2015). Self-efficacy, learning strategies, and academic achievement among Malaysian future educators. Jurnal Pemikir Pendidikan, 6(31), 31-48.

Zafari, M., \& Biria, R. (2014). The relationship between emotional intelligence and language learning strategy use. Procedia - Social and Behavioral Sciences, 98, 1966-1974.

Zarafshan, M. (2012). The relationship between emotional intelligence, language learning strategies and English proficiency among Iranian EFL university students. Journal of Educational and Instructional Studies in the World, 2(3), $105-114$.

Zarezadeh, T. (2013). The effect of emotional intelligence in English language learning. Procedia - Social and Behavioral Sciences, 84, 1286-1289.

Zhang, L. (2008). Constructivist pedagogy in strategic reading instruction: exploring pathways to learner development in the English as a second language (ESL) classroom. Instructional Science, 36, 89-116.

Zhicheng, Z. (1992). The effects of teaching reading strategies on improving reading comprehension for ESL learners. In Paper presented at the annual meeting of the Mid-south educational research association, Knoxville, TN.

Zhussupova, R., \& Kazbekova, M. (2016). Metacognitive strategies as points in teaching reading comprehension. Procedia - Social and Behavioral Sciences, 228, 593-600.

\section{Submit your manuscript to a SpringerOpen ${ }^{\circ}$ journal and benefit from:}

- Convenient online submission

- Rigorous peer review

- Open access: articles freely available online

- High visibility within the field

- Retaining the copyright to your article 